\title{
A new species of the genus Macrocentrus Curtis, 1833 from Jammu and Kashmir (UT), India
}

\begin{abstract}
Zaheer Ahmed*
Entomology Research Laboratory, Department of Zoology, University of Kashmir, Srinagar-190006 (Jammu and Kashmir), India

Altaf Hussain Mir

Entomology Research laboratory, Department of Zoology, University of Kashmir, Srinagar -190006 (Jammu and Kashmir), India

Mohd Kamil Usmani

Section of Entomology, Department of Zoology, Aligarh Muslim University, Aligarh 202002 (Uttar Pradesh), India

*Corresponding author. E-mail: zaheermir1979@gmail.com

Abstract

The genus Macrocentrus Curtis, 1833 is extensively dispersed with 238 species known worldwide. Including this new species, eight species of Macrocentrus are known from India. This genus is characterized by following characters: Antenna often about as long as or somewhat longer than the body (but sometimes distinctly shorter), with 24-61 segments, apical segment with distinct spine or without a spine. In the present study a new braconid, Macrocentrus hayati sp. nov. is described and illustrated from Jammu and Kashmir (UT), India. Specimens were collected from the grass (Cynodon) and weeds near the vegetables like brinjal, potatoes and beans through net sweeping. The collected material was transferred to glass vials containing $70 \%$ ethyl alcohol and brought to the laboratory for further studies. The study will help to boost the knowledge of Braconid parasitoids (living weapon) which play a key role in controlling the harmful pests, ultimately resulting in the increase of the yield of crops and other economic commodities like food grains.
\end{abstract}

Keywords: Braconidae, Macrocentrinae, New species, Taxonomy

\section{Article Info}

https://doi.org/10.31018/

jans.vi.2258

Received: April 22, 2020

Revised: May 5, 2020

Accepted: May 10, 2020

\section{How to Cite}

Ahmed, Z. et al. (2020). A new species of the genus Macrocentrus Curtis, 1833 from Jammu and Kashmir (UT), India. Journal of Applied and Natural Science, 12(2): $115-118$ https://doi.org/10.31018/ jans.vi.2258

\section{INTRODUCTION}

The subfamily Macrocentrinae (Hymenoptera: Braconidae) is cosmopolitan having 236 described species in eight genera (Yu et al., 2005). Most of the species of this subfamily are endoparasitic koinobionts of lepidopteran larvae e.g. Noctuidae, Tortricidae and Pyralidae (Van Achterberg and Belokobylskij, 1987, Shaw and Huddleston, 1991) smaller species are gregarious and polyembryonic (Wharton 1997). The genus Macrocentrus Curtis, 1833 is extensively dispersed with 238 species known worldwide (Yu et al., 2019). Only seven species, M. collaris (Spinola 1808), M. crassinervis Nixon 1950; M. Nixoni (Kurhade and Nikam, 1998) M. persephone (Nixon 1950) M. trimaculatus (Cameron 1910), M. turkestanicus (Telenga 1950) and Macrocentrus delhiensis (Akhtar et al., 2014) are known from India (Nixon, 1950; Saxena 1980, Khan et al. 1991, Kurhade and Nikam, 1998). This genus is characterized by following characters: Antenna often about as long as or somewhat longer than body (but sometimes distinctly shorter), with 24-61 segments, apical segment with distinct spine or without spine; vein $r$ -m of fore wing sometimes absent; ovipositor sheath clearly longer than the height of metaso$\mathrm{ma}$, at least $0.2-2.7 x$ as long as fore wing; vein $\mathrm{RS}$ of hind wing at most to some extent bent; dorsal setae on fore femur are comparatively shorter than the ventral setae which are more uniform in length (Achterberg, 1993; Wharton, 1997). In the present work, a new species, Macrocentrus hayati sp. nov. is reported from Union Territory of Jammu and Kashmir, India.

\section{MATERIALS AND METHODS}

The specimens were collected from grass (Cynodon) by using the sweeping net. The collected material was transferred to glass vials containing $70 \%$ ethyl alcohol and brought to the laboratory for further studies. A complete record was maintained indicating the locality, date of collection, name of the host plant. The slides and card mount specimens were examined under the binocular microscope. The ocular micrometre was 
used to measure (linear side of 100 divisions) fitted in one of the two eyepieces of the binocular. The ocular micrometre was calibrated with the help of stage micrometre under $8 \times 10 \times$ magnifications. Photographs were taken at different magnifications (4-16x) by the camera attached to Stereozoom binocular (SMZ1500) and Nikon SMZ 25 . The terminology and the venation were followed by Achterberg (1993), and for surface sculpture by Eady (1968) has been followed. Abbreviations used in the text are; $\mathrm{AOL}=$ Anterior ocellar line; $\mathrm{POL}=$ Posterior ocellar line; $\mathrm{OOL}=$ Ocello ocular line; OOD= Ocellus diameter; $\mathrm{F}$ : Flagellomere; $\mathrm{T}=$ Thorasic terga; $1-\mathrm{CU} 1=$ first $\mathrm{cu}-$ bitus, $2-\mathrm{CU} 1=$ second cubitus, $3-\mathrm{CU} 1=$ third cubitus. MDZUK= Museum Department of Zoology, University of Kashmir

\section{RESULTS AND DISCUSSION}

\section{Macrocentrus hayati sp.nov.}

(Figs : A-J)

Female, Body length: $4.75 \mathrm{~mm}$; Forewing: $4.75 \mathrm{~mm}$.

Head: The width of the head in dorsal view $2 x(x=$ times) its length and $1.7 x$ its height; occipital carina absent; length of the eye in lateral view $1.2 x$ its width and 2.7x its temple; OOL:POL:AOL:OOD= $9: 6: 4: 3$; Vertex smooth and punctulate; width of vertex $3 x$ its length; frons rugulose, width of frons $4 x$ its height; face smooth and sparsely setose, width of face $1.7 x$ its length; tentorial pits deep and wide; intertentorial line as long as tentorioocular line; length of malar space $1.4 x$ basal width of mandible; clypeus punctate and sparsely setose, length of clypeus $2 x$ its width; maxillary palpi five segmented, longer than fore coxa ; antennal segments 32 ; scape and pedicel as long as wide, apical segment of antenna $2 x$ as long as wide, length of $F_{1}$ 5.3x: $F_{2} 4 x: F_{3}-F_{4}$ 3.6x: $F_{5}-F_{6} 3.3 x: F_{7}$ 3x: $F_{8} 2.6 x: F_{9} F_{15} 3.5 x: F_{16}-F_{24} 2.5 x: F_{25}-F_{30} 2 x$ their widths respectively.

Mesosoma: Length of mesosoma $2.8 \mathrm{x}$ its width and $2.1 \mathrm{x}$ its height; dorsal surface of pronotum aciculate, rugose laterally; notauli deep, broad and crenulate throughout; mesopleuron somewhat rugose, metapleuron coriaceous reticulate; scutellar sulcus deep without any median cariana except few carinae basally; dorsal surface of scutellum smooth, laterally punctate; sternulus reticulate; metanotum coracious reticulate; mesoscutum dorsally smooth laterally punctate; propodeum entirely reticulate rugose.

Legs: Hind coxa $2.3 x$ as long as wide; length of the hind femur, tibia, and basitarsus8.2x, 11.2x and $12.3 x$ their width respectively; length of hind tibial spur $0.27 x$ hind basitarsus.

Wings: Length of forewing 3.6x its width, length of pterostigma $4 x$ its width, length of vein $1-R 11.2 x$ length of pterostigma; vein $r$ arising middle of pterostigma; m-cu interstitial, cu-a postfurcal;

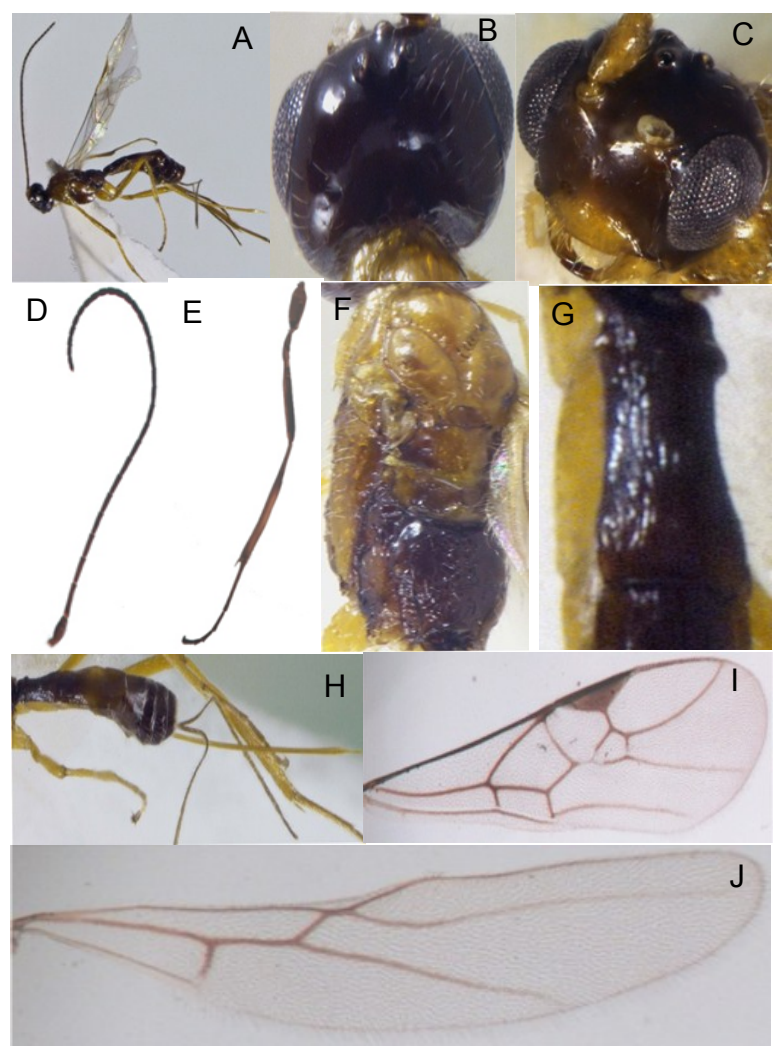

Figs. A-J. Magnification 4-16x) Female Macrocentrus hayati sp. nov. A. Habitus B. Dorsal head $C$. Frontal head D. Antenna E. Hind leg F. Mesosoma dorso-lateral G. First metasomal tergite H. Metasoma dorsal I. Fore wing J. Hind wing.

SR1+3-SR curved; r: 2-SR:S-R1+3-SR = 5:9:56; 1 -CU1: 2-CU1: 3-CU1 = 3:23:6; length of hind wing 4.6x its width; $1 \mathrm{M}: 1-\mathrm{r}-\mathrm{m}: 2-\mathrm{SC}+\mathrm{R}=16: 7: 5$.

Metasoma: Length of metasoma $5 x$ its width and $4.5 \mathrm{x}$ its height nearly as long as head and mesosoma combined; $\mathrm{T}_{1}$ anterio-medially rugose remaining striate, $2.14 \mathrm{x}$ as long as wide at spiracles, $1.4 x$ length of $T_{2} 2.5 x$ length of $T_{3}, T_{2}$ longitudinally striate, $T_{3}$ and remaining terga smooth and densely setose ; length of first metasomal tergite $3.18 x$ its apical width; apical width $1.9 x$ its basal width; dorsope present; spiracles present apically; ovipositor long and pointed at apex, length of ovipositor sheath $0.54 x$ forewing.

Colour: Head black, wings transparent with brown venation, antenna uniformly dark brown, legs yellowish brown except, telotarsus and claw dark brown, face dark brown, clypeus yellow, mandibles yellow with black teeths, maxillary and labial palpi yellowish, eyes greyish, ocelli transparent, ocellar area dark brown, mesosoma yellowish brown except propodeum dark brown, first metasomal tergite dark brown, second metasomal tergite brown and remaining tergites dark brown, ovipositor yellow and ovipositor sheaths brown.

Type material: Holotype 1q, Paratypes $3 q \circ$, INDIA: Jammu and Kashmir, Poonch, Haveli, 
12.v.2019, Coll. Zaheer Ahmed. Holotype deposited in (MDZUK)

Etymology: Species has been named in honour of Mohd Hayat for his contribution towards the knowledge of parasitic Hymenoptera.

Male ${ }_{0}$ : Unknown

Host: Unknown

\section{DISCUSSION}

So far, seven species of Macrocentrus are reported from India.

Macrocentrus persephone Nixon, 1950, Body length: $\delta q=6.5-7.5 \mathrm{~mm}$. (without ovipositor of +). Distribution, India, S. Coorg, Tithimatti, 4. x. 1942, (2아), 18. x. 1942, 1 + (the type), 30. x. 1942, all ex Microlepidopteron defoliating Bauhinia $s p$. Type in the British Museum (Natural History).

Macrocentrus crassinervis, Nixon, 1950, Body length: $\hat{\delta} Q=6 \mathrm{~mm}$. (without ovipositor of +).Distribution, INDIA : Madras, Wynaad, Kannoth Range,11. iv. 1946, Iđ, 1. vii. 1946, 1ठ, 1ㅇ, 8. vii. 1946, 1 (the type), all ex Symithanolalella Walker, defoliating Lagerstroemia parviflora (F.R.I. Project). Type in the British Museum (Natural History).

Macrocentrus delhiensis Akhtar et al. 2014, Body length: $q=5.8 \mathrm{~mm}$. (without ovipositor of +).Distribution, + : INDIA: Delhi, New Delhi, Pusa campus, IARI, weeds near mango orchards, deposited in the National Pusa Collection, Division of Entomology, Indian Agricultural Research Institute, New Delhi (NPC).

Macrocentrus trimaculatus (Cameron), Leptozele trimaculatus Cam., 1910. Body length (q): $5.2 \mathrm{~mm}$ (excluding ovipositor) Tijd. v. Ent. liii. p. 52. CeyIon. Macrocentrus trimaculatus (Cam.), Nixon, 1939, Bull. ent. Res. xxix. p. 423. Distribution 9 ; India, Madras.

Macrocentrus nixoni (Kurhade and Nikam, 1998). Body length ( $q$ ) : $4.9 \mathrm{~mm}$ (excluding ovipositor) Antenna with 47 segments, scape $2.4 x$ as long as wide, propodeum with transverse carina, basallay longitudinally strigose.

Macrocentrus collaris (Spinola, 1808). Body length (ㅇ): $5.0 \mathrm{~mm}$. (excluding ovipositor). Antenna with 42 segments, clypeus slightly convex, wider than long (i.e. transverse), face smooth medially, temple smooth and shiny, propodeum coarsely, transversely rugose.

Macrocentrus mandibularis Watanabe, 1967. Vertex smooth and shiny, ocelli small, Antenna short with 36 segments. Distribution; Europe, Japan. Holotype ( $q$ ) and paratypes $(9 q+q), 6\left(\widehat{\partial} \delta^{\lambda}\right)$ : Omagari, Akita-ken, 23-viii-64, bred from a larva of Archips fuscocupreanus, T. Hidaka leg. Paratype (19): Sapporo, 13-viii-64, K. Kusigemati leg. Host. This species has been bred from the larva of $A$. fuscocupreanus Walsingham living in the rolled leaf of Agrostis sp.
The new one Macrocentrus hayati sp. nov. closely resembles Macrocentrus mandibularis Watanabe, 1967. However, it differs from this species in certain peculiar characteristics as follows:

Most of the species of this subfamily are endopar-

\begin{tabular}{|c|c|}
\hline $\begin{array}{l}\text { Macrocentrus mandibu- } \\
\text { laris Watanabe, } 1967\end{array}$ & $\begin{array}{l}\text { Macrocentrus hayati sp. } \\
\text { nov. }\end{array}$ \\
\hline 1. Antennal segments 36 & 1. Antennal segments 32 \\
\hline $\begin{array}{l}\text { 2. Malar space } 2 x \text { basal } \\
\text { width of mandible }\end{array}$ & $\begin{array}{l}\text { 2. Malar space } 1.4 \mathrm{x} \text { basal } \\
\text { width of mandible }\end{array}$ \\
\hline $\begin{array}{l}\text { 3.Intertentorial line } 1.5 x \\
\text { tentorio-ocular line }\end{array}$ & $\begin{array}{l}\text { 3. Intertentorial line as long } \\
\text { as tentorio-ocular line }\end{array}$ \\
\hline $\begin{array}{l}\text { 4. First metasomal tergite } \\
9 x \text { as long as wide }\end{array}$ & $\begin{array}{l}\text { 4. First metasomal tergite } \\
5.3 x \text { as long as wide }\end{array}$ \\
\hline $\begin{array}{l}\text { 5. Propodeum irregularly } \\
\text { transversely rugose. }\end{array}$ & $\begin{array}{l}\text { 5. Propodeum entirely } \\
\text { reticulate rugose }\end{array}$ \\
\hline
\end{tabular}

asitic koinobionts of lepidopteran larvae, e.g. Noctuidae, Tortricidae and Pyralidae, and smaller species are gregarious and polyembryonic. The addition of a new species to Braconid parasitoids (living weapon) may play a key role in controlling the harmful pests, ultimately increasing the yield of crops and other economic commodities like food grains.

\section{Conclusion}

In the past studies, very little work has been done on braconid wasps of Jammu and Kashmir, India. Thus identification of new species of genus viz., Macrocentrus hayati sp. nov. from the Union Territory (UT) of Jammu and Kashmir has both taxonomic as well as ecological importance and will increase the knowledge of Braconid parasitoids playing a significant role in controlling the harmful pests.

\section{ACKNOWLEDGEMENTS}

We are thankful to the anonymous reviewer for valuable comments and suggestions. We thank Dr. Mohammad Shamim (Principal Investigator DST SERC, Young Scientist, Section of Entomology, Department of Zoology, Aligarh Muslim University) for his suggestions on this manuscript. We also thank the Chairman, Department of Zoology, Aligarh Muslim University for the laboratory facilities.

\section{REFERENCES}

1. Achterberg, C. van and S.A. Belokobylskij, (1987). Revisionary notes on the Macrocentrinae from the Far East USSR (Hymenoptera, Braconidae). Zool. Med. Leiden 61: 243-262, figs 1-100.

2. Achterberg, C. van. (1993). Revision of the subfamily Macrocentrinae Foerster (Hymenoptera: Braconidae) from the Palaearctic region. Zoologische Verhandelingen Leiden 286:1-110.

3. Achterberg, C. van. (2001). Macrocentrus sylvestrellae spec. nov. (Hymenoptera: Braconidae: Macrocentrinae), a parasitoid of Dioryctriasylvestrella (Ratzeburg) (Lepidoptera: Pyralidae). Article in Zoologische Mededelingen 75 (4): 79-88. 
Ahmed, Z. et al. / J. Appl. \& Nat. Sci. 12(2): 115 - 118 (2020)

4. Akhtar, M. S. Longjam, R. K. S. and Ramamurthy, V. V. (2014).New species of the genus Macrocentrus Curtis 1833,(Hymenoptera: Braconidae) from India. The Pan-pacific Entomologist 90 (1): 11-15DOI: http://dx.doi.org/10.3956/2014-90.1.11

5. Eady, R. D (1968) Some illustrations of micro sculpture in the Hymenoptera, Pro-ceeding of Royal Entomological Society London 43(4-6): 66-72. Khan, Z. R., Litsinger, J. A. Barrion, A. T. Villanueva, F. F. D.Fernandez, N. J. and Taylo L. D(1991). World Bibliography of rice stem borers 1974-1990. International Rice Research Institute and International Centre of Insect Physiology and Ecology, $415 \mathrm{pp}$.

6. Kurhade, S. M. andNikam, P. K.(1998). A new species of Macrocentrus Curtis (Hymenoptera: Braconidae) from India. Journal of the Bombay Natural History Society 95(2):307-309.

7. Nixon, G. E. J. (1950). New Indian Braconidae bred from lepidopterous defoliators (Hymenoptera). Annals and Magazine of Natural History. 12 (3):453-474.http:// dx.doi.org/10.1080/00222935008654071

8. Saxena, A. P. (1980). Biology of Macrocentrus collaris Spinola (Hymenoptera: Braconidae). Potato Journal. 7(4):167-173.
9. Sharkey, M. J. and Wharton, R. A.(1997). Morphology and terminology, pp. 19-37. In: Wharton, R. A., P. M. Marsh and M. J. Sharkey (Eds.), Manual of the New World Genera of the Family Braconidae (Hymenoptera). Special Publication of the International Society of Hymenopterists 1, 439 pp.

10.Shaw, M. R. and T. Huddleston, 1991. Classification and biology of braconid wasps (Hymenoptera: Braconidae). Handbook for identification of British insects. 7(11): 1-126.

11.Watanabe. C. (1967).Further revision of the genus Macrocentrus Curtis in Japan with descriptions of two new species (Hymenoptera: Braconidae), Insecta Matsumurana, Vol. 30, No.1:1-18.

12.Wharton, R. A. (1997). Subfamily Macrocentrinae, pp. 311-315. In: Wharton, R. A., P. M. Marsh and Sharkey, M. J. (Eds.), Manual of the New World Genera of the Family Braconidae (Hymenoptera). Special Publication of the International Society of Hymenopterists 1, $439 \mathrm{pp}$.

13. Yu, D. S., C. V. Achterbergand K. Horstmann. (2005) accessed (2019). Biological and taxonomical information: Ichneumonoidea 2004 -Taxapad Interactive Catalogue, Vancouver. 